p. 320

怵青兴研究

\section{スボーツの域合绵面の研究 筑二報}

奈良学筀大学 ○辻本 觔, 近藤 英物 竹村 抳

試合場面の獚成荘䇣としては自己，相手，審判，伈援， 場所等があり第一報では相手に関して体育社会学的立場 より考察したが第二報は審判についての研究である.審 判には客锶的判断によるるのと主钼的判断に上るものと の二類型に分けられるが後者には各種の問䞨が含まれる と思われるのでハンーボールを取上げその問垶を解明分 析せんとした．奈良県下高校ハレー選手男女䄪 600 名を 対象に貿問紙法で差施した。

\begin{tabular}{|c|c|c|c|c|c|c|}
\hline 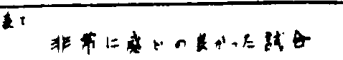 & 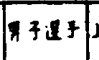 & $5(x+-2$ & $T+t+4$ & +325 & $2 x+-4$ & $T x^{+x-1}$ \\
\hline 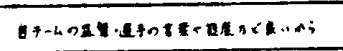 & $25.9^{7}$ & $10.0^{*}$ & 31.4 & $22.0^{\circ}$ & $15.4^{n}$ & $10.9^{x}$ \\
\hline 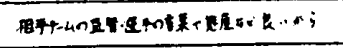 & 419 & 52.0 & 27.8 & 39.0 & 48.1 & 51.6 \\
\hline 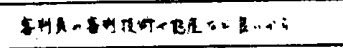 & 20.9 & 28.0 & 22.2 & 29.0 & 32.7 & 25.0 \\
\hline 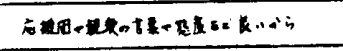 & 6.8 & 8.0 & 7.4 & 5.3 & 1.9 & 4.7 \\
\hline 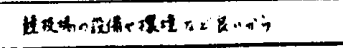 & 4.5 & 2.0 & 112 & 4.7 & 1.9 & 7.8 \\
\hline 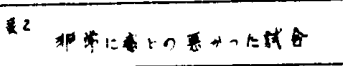 & Rist & -4 & $F(\mathbf{L}+L \mid$ & tzity & Ext $x+4$ & $T(1)+i$ \\
\hline 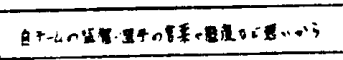 & $5.9^{\circ}$ & $8.0^{\circ}$ & 5.5 & 10.0 & $5.8^{4}$ & $7.8^{7}$ \\
\hline 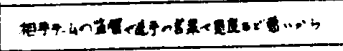 & 33.2 & 30.0 & 35.2 & 37.3 & 34.6 & 42.2 \\
\hline 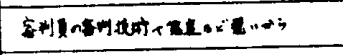 & 40.5 & 50.0 & 38.9 & 31.0 & 48.1 & 17.2 \\
\hline 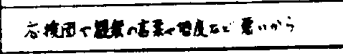 & 15.0 & 8.0 & 16.7 & 18.7 & 11.5 & 31.2 \\
\hline X) & 5.4 & 4.0 & 3.7 & 3.0 & 0 & 1.6 \\
\hline
\end{tabular}

\begin{tabular}{|c|c|c|c|c|c|c|}
\hline 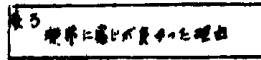 & 784 & I & & 18 & Eat.4 & Tritt. \\
\hline$A k+12$ & $4.5^{2}$ & 7.4 & $1.0^{\circ}$ & $5.2^{2}$ & $5.9^{\circ}$ & \\
\hline Himba & 21.4 & 17.9 & 20.0 & 17.0 & 13.8 & 21.4 \\
\hline 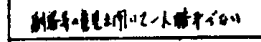 & 13.1 & 15.8 & 17.0 & 9.0 & 14.1 & 9.5 \\
\hline 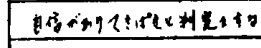 & 10.9 & 8.4 & 8.0 & 11.3 & 9.8 & 13.1 \\
\hline प्रका & 7.3 & 10.5 & 4.0 & 8.3 & 7.8 & 10.3 \\
\hline 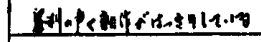 & 14.2 & 12.6 & 17.0 & 12.3 & 11.8 & 11.1 \\
\hline An & 1.8 & & 2.0 & 2.9 & 2.7 & 40 \\
\hline Shat & 12.4 & 16.9 & 13.0 & 17.8 & 19.7 & 12. \\
\hline$(1,+4)$ & 5.5 & 6.3 & 6.0 & 5.8 & 5.9 & 7.1 \\
\hline f酶 & 8.9 & 4.2 & 12.0 & 10.4 & 78 & 12.0 \\
\hline$\sqrt{4}$ & 4 & & & & & \\
\hline Lste & 6.5 & 10.51 & $7.0^{\circ}$ & $7.1^{\circ}$ & $8.8^{4}$ & $6.4^{x}$ \\
\hline AnB & 4.2 & 2.1 & 3.0 & 1.7 & 0.9 & 2.4 \\
\hline$=31 L_{i} 213-30$ & 8.5 & 9.5 & 6.0 & 8.2 & 5.9 & 14.3 \\
\hline 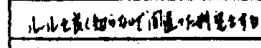 & 10.0 & 10.5 & 11.0 & 12.4 & 10.8 & 12.7 \\
\hline 连.54 & 19.1 & 21.0 & 17.0 & 20.9 & 27.5 & 17.5 \\
\hline 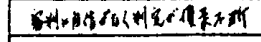 & 12.9 & 11.6 & 14.0 & 120 & 118 & 11.1 \\
\hline 14 & 10.9 & 11.6 & 10.0 & 12.2 & 13.8 & 13.5 \\
\hline 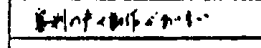 & 8.2 & 6.3 & 8.0 & 10.8 & 6.9 & 10.3 \\
\hline 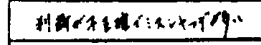 & 15.3 & 13.7 & 18.0 & 11.5 & $\therefore 1.8$ & 6.4 \\
\hline MEETCF & 4.4 & 3.2 & 6.0 & 3.2 & 1.8 & 5.4 \\
\hline
\end{tabular}

結果及考察 先つ選手から見て試合の感じが良かつた 場合と悪かつた場合において審判買の占めるウエイトを

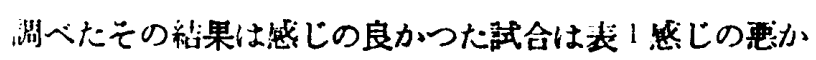
つた試台は表 2 の如くで男女別では同じ傾向を示してい るが上下位別ではかなりの差が表われており一般的に上 位チームは下位に比し審判員により多くの閴心を示して いる。これは試合経験が費富になり技術が上達しルール をマスターするに従つて番判に対する関心が高まつてい く事を示し特に感じの悪い試合ではより大きく表われて いることを明らかにしている。

次に審判員の態度や審判技術を通手が感じの良かつた 試合と要かつた試合の各々の理由について調べたその結 果は，表 3 及び表4の如くで良かつた理由では男女とも ほメ゙同頋向であり，感情的にならない，公平であるの理 由が高い、男子上下位別では下位は試合運営,ミスジ ツジがない等審判技術的な理由が少いのは審判への関 心が上位上り低く，逆に真面目の理由が多いのは下位 チームの特性を現わしていると思われる悪かつた理由 では䫓著な差はなく，不公平であるの理由に集中して いる. 一般的に審判態度の理由を多くの選手が指摘し ていることは主観的判断を主とするパレボールのむ つかしさを示するのである。

結語 各項にわたつて考察したがそれらを要䄪する とスポーツの試合場面では選手にとつて相手並に審判 の要素が非常に大きなウェイトを占めており，特に： レーボールに怙いては感じが覀かつた試合では審判技術 や審判態度が大きく選手に影掣を及ばしていることが 伺われる，なほ男女の性差及び技術の传多によつても䫒 著な差異が認められる。このようにバレーボールにおい ては子期以上に審判員にかけられているウェイトは大き く種々の問題がひそんでいるので今後審判員の主体性の 確立一の努力は勿論審判技術の向上，練磨特に審判技術 修得の方法論の研究がなされなければならないと思うの である。

問 審判員の定楼を「媒介者」としているがどらいら ことか. 概念規定によつて㥶判のありかたは变つてくる と思われるが。

（京都市立紫野高校・竹内）

答 ハレーボールにおいては審判は単に Manager 的 役割を果すのみでなく，勝負を左右する存在であり，活 合場面を構成する重要な Part としての役割をもつてい るので、「媒介者」といら概念を用いた。

(近藤) 